\title{
Oral health educative-preventive program at school
}

\section{Programa educativo-preventivo em saúde bucal na escola}

\section{Patrícia Aleixo dos SANTOS}

Post-graduating in Dentistry - São Paulo State University - UNESP - MS, Professor of Odontology in Collective Health from University Center of Araraquara - UNIARA - Araraquara - SP - Brazil

\section{Juliana Alvares Duarte Bonini CAMPOS}

DDS, MS, PhD, Professor of Biostatistics and Scientific Methodology - São Paulo State University - UNESP Araraquara - SP - Brazil.

\section{Carlos Henrique Braga BORGES}

Graduate student, Department of Odontology - University Center of Araraquara - UNIARA - Araraquara - SP - Brazil.

\section{Natália Apolinário de LIMA}

Graduate student, Department of Odontology - University Center of Araraquara - UNIARA - Araraquara - SP - Brazil

\begin{abstract}
This study has the aim of evaluation two different educational methods as: explanatory folders and lectures, at the implementation of an educative-preventive program about oral health developed at elementary public schools in Araraquara (SP) city. The sample was constituted by schoolchildren from fifth and sixth grades of four schools selected by convenience, divided in two groups: GA $(n=303)$ that received only the folders and GB $(n=245)$ that read the folders and also attended lectures. A questionnaire was applied before and fifteen days after program. The distribution of frequency was calculated and after that, to intergroup comparison chi-square test was used, and intragroup, the McNemar test $(\alpha=0,05)$. Most of schoolchildren understand that the consumption of sugary food has to be done after main meals and they are able to associate sugar consumption with tooth decay, beyond they do not know that sugar belongs to carbohydrates group. A healthy meal was considered dependent of type of food for $52 \%$ of GA and $44 \%$ of GB before the program, and $48 \%$ and $39 \%$ fifteen days after it. Initially, only $31 \%$ of GA and $30 \%$ of GB knew the ideal moment for tooth brushing. Methods of plaque prevention seemed familiar to schoolchildren. There was a difficulty to define the features of periodontal disease. At intergroup analyses, there was statistical difference to questions 3,5,6,8 and 11, comparing two moments; at intragroup analyses, GA showed significant knowledge change only to question 4 while for GB, same occurred to questions 3,4,5,6,8 and 11, accusing more effectiveness to educational method adopted by GB. The isolated use of the folder has not increased the level of oral health information while the association of folder with lectures increased their knowledge.
\end{abstract}

\section{UNITERMS}

Primary education; dental health education; teaching materials.

\section{INTRODUCTION}

The prevention of oral illness such as tooth decays and periodontal disease have represented the great aim of educative-preventive programs concerned to oral health promotion ${ }^{7,8,10}$.

The health education process consists of modifying attitudes and behavior of the population intending to improve their own health, according to Mastranto- nio and $\mathrm{Garcia}^{10}(2002)$ and for that, it is necessary that the educative programs are able to call the attention of the target public ${ }^{4,17}$.

According to Tamietti et al. ${ }^{18}$ (1998) in order to the interaction with target public occurs, problems of health and illness that afflict them have to be analyzed along with the way they see their own health problems 
with the intention of preparing programs with appropriated language and coherent proposals that may transform its habits and attitudes ${ }^{6,13}$.

School is a place where children spend great part of their life and act significantly at opinion's formation, so, it is considered a reference to implementation of any program that is proposed to develop the education and awareness of the general public. Most of children and teenagers spend daily from 4 to 5 hours at school and during this time the learning process is established and family habits may suffer influences ${ }^{3}$. Waldman ${ }^{20}$ (1998) reports and interchange among habits obtained in familiar center and that obtained at school, which complete each other and are reinforced when presented frequent and appropriately.

In this way, this study has the aim of evaluation two different educational methods as: explanatory folders and lectures, at the implementation of an educative-preventive program about oral health developed at elementary public schools in Araraquara (SP) city.

\section{Material and Method}

This is a study developed with convenience sampling where, after receiving a list that contained all the names of grade schools from Araraquara-SP Brazil, when four schools were picked and the institutions were consulted about taking part in the previously mentioned program and confirmed their acceptance.

To the carrying out the educative-preventive program, two students from sixth semester of graduation of Dentistry course at Araraquara University Center UNIARA used folders of instruction made specially to this purpose and educative lectures, both approaching themes such as periodontal disease, dental caries, oral hygiene and feeding.

The sample was constituted by schoolchildren from fifth and sixth grade so that from the moment of the random selection half of them received only the brochure ( group A - GA) and the other half attended lectures besides the reading material (group B - GB).

Originally, schoolchildren from both groups received a questionnaire with objective questions, previously tested, presenting great agreement $(\kappa=$ 0.92 ), regarding to the over mentioned oral health themes that were answered in writing without any kind of previous orientation and surpervision. It has to be emphasized that the referred instrument was prepared with only one correct answer.
After answering the questionnaire, the groups received the folder and it was pointed out the importance of reading it at home was pointed out so that information about oral health could be learned. Group B, as soon as folders were handed, has participated to lectures given by Dentistry students with aid of slides projector containing slides of clinical cases and theoretical concepts about periodontal disease, dental caries, oral hygiene and feeding that lasted for about 30 minutes.

After two weeks, the school was visited again and schoolchildren received the same questionnaire to be answered for a second time. The compliance rates of schoolchildren from first and second periods were $8 \%$. At the end of this period, groups A and B were composed by 303 and 245 participants respectively, and that in group GA $56 \%$ of the children attended the fifth grade (eleven years old) and $44 \%$ the sixth grade (twelve years old) while in the GB group the figures were $60 \%$ and $40 \%$ respectively, what shows the homogeneity among the groups.

The answers were categorized and presented by the distribution of frequency with aid of Excel Program. Next, the answers were classified in "right" or "wrong" to evaluate the knowledge in relation to oral health of schoolchildren from different groups (GA, GB) after 15 days of program through chi-square test. To compare the knowledge intragroups, before and after program, McNemar test was used. These tests were done at BioEstat 3.0 Program and the significance level adopted was $5 \%$.

It has to be emphasized that this study was approved by Ethics in Research Commitee from Araraquara University Center - UNIARA under protocol \# 345/2005.

\section{Results}

The absolute (n) and relative (\%) frequencies of schoolchildren' answers, from different groups at two moments of evaluation referring to the knowledge about food consumption and oral health may be observed at Table 1 .

It may be observed that most of schoolchildren understand that the consumption of sugary food must be done after main meals, however it is important emphasize that more than $10 \%$ of this people from different groups without distinction of moment of evaluation, believe that they may consume candy and sweet whenever they feel like and a similar number of people said that they should never consume these products, showing that there was a less of agreement about rational use of sugary food. 
Table 1 - Distribution of frequencies $(\mathrm{n}(\%))$ of schoolchildren' answers referents to knowledge about food consumption and oral health. Araraquara, 2006.

\begin{tabular}{|c|c|c|c|c|}
\hline \multirow[t]{2}{*}{ QUESTIONS } & \multicolumn{2}{|c|}{ GA } & \multicolumn{2}{|c|}{ GB } \\
\hline & before & after 15 days & before & after 15 days \\
\hline \multicolumn{5}{|l|}{ Question 01} \\
\hline Always he/she wants & $41(14)$ & $38(13)$ & $30(12)$ & $27(11)$ \\
\hline After main meals & $213(70)$ & $217(72)$ & $165(67)$ & $179(73)$ \\
\hline All day long & $8(3)$ & $7(2)$ & $5(2)$ & $8(3)$ \\
\hline Never & $41(14)$ & $41(14)$ & $45(18)$ & $31(13)$ \\
\hline \multicolumn{5}{|l|}{ Question 02} \\
\hline No answer & $0(0)$ & $4(1)$ & $14(6)$ & $9(4)$ \\
\hline Dental carie & $279(92)$ & $275(91)$ & 219 (89) & $220(90)$ \\
\hline Belly pain & $14(5)$ & $13(4)$ & $2(1)$ & $7(3)$ \\
\hline Tooth loss & $4(1)$ & $5(2)$ & $4(2)$ & $4(2)$ \\
\hline Câncer & $6(2)$ & $6(2)$ & $6(2)$ & $5(2)$ \\
\hline \multicolumn{5}{|l|}{ Question 03} \\
\hline No answer & $6(2)$ & $2(1)$ & $9(4)$ & $2(1)$ \\
\hline Lipid & $182(60)$ & $187(62)$ & $173(71)$ & $109(44)$ \\
\hline Protein & $15(5)$ & $15(5)$ & $17(7)$ & $9(4)$ \\
\hline Carbohidrate & $82(27)$ & $86(28)$ & $33(13)$ & $116(47)$ \\
\hline Vitamin & $18(6)$ & $11(4)$ & $13(5)$ & $8(3)$ \\
\hline I don't know & $0(0)$ & $2(1)$ & $0(0)$ & $1(0)$ \\
\hline \multicolumn{5}{|l|}{ Question 04} \\
\hline No answer & $5(2)$ & $2(1)$ & $5(2)$ & $6(2)$ \\
\hline Type of food, consistency e frequency of ingestion & $101(33)$ & $139(46)$ & $88(36)$ & $116(47)$ \\
\hline Type of food & $157(52)$ & $145(48)$ & $109(44)$ & $96(39)$ \\
\hline Frequency of ingestion & $15(5)$ & $10(3)$ & $9(4)$ & $12(5)$ \\
\hline No one above & $25(8)$ & $7(2)$ & $34(14)$ & $15(6)$ \\
\hline
\end{tabular}

Regarding the excessive consumption of sugar, most of the children presented tooth decay. When questioned about which group of food was responsible for the presence of tooth decay, $60 \%$ of GA and $71 \%$ of GB gave the credit to the lipid and only $27 \%$ and $13 \%$ of these groups, respectively, quoted carbohydrates as responsible at the first moment (before program) and 28\% and $47 \%$ after program, showing effectiveness of lectures.

Regarding to the features of a meal which helps the maintenance of oral health, $52 \%$ of group A and $44 \%$ of group B, before program, and 48\% and 39\%, 15 days after program, pointed out that the type of food has to be observed, while $33 \%$ of GA and $36 \%$ of GB noted the necessity of observing consistency of food and frequency of ingestion besides the type in the initial moment, and $46 \%$ and $47 \%$ respectively after program.
The amount of the school children's answers when asked about the ideal moment for tooth brushing and the necessity of this in babies, may be observed in Table 2.

In this Table 2, it is important to note that the answer with higher frequency, before program, was referent to the necessity of toothbrush four times a day and only $31 \%$ of GA and $30 \%$ of GB answered this question correctly. After 15 days from program execution, GA almost maintained the percentage of correct answers while GB showed a considerable increase of this number. In relation to babies' toothbrushing, before program, $73 \%$ of GA and $69 \%$ of GB believed that it was necessary, and after two weeks there was a change in the pattern of the answers only from GB group, totalizing $91 \%$ of the answers. 
Table 2 -Distribution of frequencies $(\mathrm{n}(\%))$ of schoolchildren' answers referents to habits of tooth brushing. Araraquara, 2006.

\begin{tabular}{|c|c|c|c|c|}
\hline \multirow[t]{2}{*}{ QUESTIONS } & \multicolumn{2}{|c|}{ GA } & \multicolumn{2}{|c|}{ GB } \\
\hline & before & after 15 days & before & after 15 days \\
\hline \multicolumn{5}{|l|}{ Question 05} \\
\hline No answer & $4(1)$ & $3(1)$ & $14(6)$ & $13(5)$ \\
\hline Before going to bed and when wake up & $5(2)$ & $3(1)$ & $2(1)$ & $4(2)$ \\
\hline After main meals & $11(4)$ & $19(6)$ & $11(4)$ & $22(9)$ \\
\hline Everytime I eat & $94(31)$ & $92(30)$ & $74(30)$ & $113(46)$ \\
\hline When wake up, after lunch and before going to bed & $64(21)$ & $80(26)$ & $44(18)$ & $31(13)$ \\
\hline Four times a day & $125(41)$ & $106(35)$ & $100(41)$ & $62(25)$ \\
\hline \multicolumn{5}{|l|}{ Question 06} \\
\hline Yes & $221(73)$ & $225(74)$ & 169 (69) & 224 (91) \\
\hline No & $75(25)$ & $74(24)$ & $69(28)$ & $20(8)$ \\
\hline No answer & $7(2)$ & $4(1)$ & $7(3)$ & $1(0)$ \\
\hline
\end{tabular}

The schoolchildren's knowledge about dental plaque concepts, the consequences of its presence and preventive measures are represented in Table 3.

The dental plaque concept was appropriately featured by $46 \%$ and $48 \%$ of schoolchildren from GA and $\mathrm{GB}$, at the first moment and by $49 \%$ and $52 \%$ after 15 days. However, it may be noted that more than $20 \%$ of them still believe that plaque is just food scraps adhered to the teeth. In relation to damages that the presence of plaque can cause, most of schoolchildren quoted oral diseases, and has to be considered that a larger percentage of GB answered correctly to this question after 15 days. Nevertheless, it has to be emphasized that in the initial moment of the study, 20\% of GA and $14 \%$ of GB believed that dental plaque causes tooth pain and at the second moment, these values were $17 \%$ and $9 \%$.

The way to prevent dental plaque was brought up in question 9 and was verified that more that a half of schoolchildren from both groups from the initial moment to the very end knew the right answer. About the ideal moment for toothbrushing, 35\% of GA and $33 \%$ of GB though that brush their teeth only before going to bed and after waking up followed by use of dental floss when they realized that there were some food scraps were sufficient measures to prevent dental plaque formation, and these data had few alteration after program execution.

The answers referents to knowledge about periodontal disease features are shown in Table 4.

Among all formulated questions to evaluate the proposed program, the ones referring to periodontal dis- eases features (Table 4) were the ones which presented the most difficulty for the schoolchildren to answer. It was noted that many of them did not know the correct answer while others did not know how to distinguish gingivitis from periodontitis, what may be observed both in question 10 and question 11 answers, in the two groups at distinct moments, despite the improvement showed by the group that attended the lectures.

The comparison of answers when grouped in 'right' and 'wrong' given by schoolchildren from GA and GB 15 days after program execution, may be observed in Table 5 .

It may be noted the statistical difference in GA and GB regarding to the knowledge about the group of food able to cause dental caries, ideal moment of tooth brushing, necessity of tooth brushing in babies, damages associated with dental plaque presence and periodontitis concept.

To measure intra-group behavior at different moments of this study, it was used the McNemar test, and the results are shown in Table 6.

According to the results above it might be verified that those group which received only the folder showed significant alteration on knowledge about food features (question 4), while at the group that had also attended the lectures there was a significant improvement on knowledge about groups of food related to dental caries, food features, ideal moment for tooth brushing, babies' tooth brushing, consequences of dental plaque presence and periodontal disease concepts, what leads to the assertion that the educational technique adopted in group B was more efficient. 
Table 3 - Distribution of frequencies $(\mathrm{n}(\%))$ of schoolchildren' answers regarding their knowledge about dental plaque concepts, the consequences of its presence and preventive measures. Araraquara, 2006.

\begin{tabular}{|c|c|c|c|c|}
\hline \multirow[t]{2}{*}{ QUESTIONS } & \multicolumn{2}{|c|}{ GA } & \multicolumn{2}{|c|}{ GB } \\
\hline & before & after 15 days & before & after 15 days \\
\hline \multicolumn{5}{|l|}{ Question 07} \\
\hline I don't know & $38(13)$ & $19(6)$ & $32(13)$ & $23(9)$ \\
\hline The remains of the meal that stay in the teeth. & $67(22)$ & $74(24)$ & $55(22)$ & $57(23)$ \\
\hline Bacterias that stay in mouth & $33(11)$ & $35(12)$ & $19(8)$ & $17(7)$ \\
\hline $\begin{array}{l}\text { Rich in bacteria and rest of food layer that remains } \\
\text { and adhere to the teeth }\end{array}$ & $140(46)$ & $149(49)$ & $118(48)$ & $128(52)$ \\
\hline Acids that destroy teeth & $25(8)$ & $26(9)$ & $21(9)$ & $20(8)$ \\
\hline \multicolumn{5}{|l|}{ Question 08} \\
\hline I don't know & $25(8)$ & $33(11)$ & $35(14)$ & $21(9)$ \\
\hline $\begin{array}{l}\text { Dental caries, Periodontal disease, bad breath mau } \\
\text { hálito }\end{array}$ & $204(67)$ & $208(69)$ & $162(66)$ & $189(77)$ \\
\hline Dental carie, tooth loss & $4(1)$ & $1(0)$ & $4(2)$ & $1(0)$ \\
\hline Bad breath, periodontal disease & $62(20)$ & $52(17)$ & $34(14)$ & $21(9)$ \\
\hline Dental carie, Oral cancer & $8(3)$ & $9(3)$ & $10(4)$ & $13(5)$ \\
\hline \multicolumn{5}{|l|}{ Question 09} \\
\hline I don't know & $11(4)$ & $22(7)$ & $23(9)$ & $18(7)$ \\
\hline $\begin{array}{l}\text { Tooth brushing before going to bed and when wake } \\
\text { up and use of dental floss when realize food stuck } \\
\text { among the teeth }\end{array}$ & $107(35)$ & $91(30)$ & $82(33)$ & $68(28)$ \\
\hline Have a healthy diet and visit the dentist & $10(3)$ & $10(3)$ & $10(4)$ & $10(4)$ \\
\hline $\begin{array}{l}\text { Tooth brushing regularly, have a healthy diet, use } \\
\text { dental floss after tooth brushing and visit the dentist }\end{array}$ & $161(53)$ & $174(57)$ & $122(50)$ & $135(55)$ \\
\hline Eat only fruits, vegetables and visit the dentist & $14(5)$ & $6(2)$ & $8(3)$ & $14(6)$ \\
\hline
\end{tabular}

Table 4 - Distribution of frequencies $(\mathrm{n}(\%))$ of schoolchildren' answers referring to knowledge about periodontal disease features. Araraquara, 2006.

\begin{tabular}{lcccc}
\hline \multicolumn{1}{c}{ QUESTIONS } & \multicolumn{2}{c}{ GA } & \multicolumn{2}{c}{ GB } \\
& before & after 15 days & before & after 15 days \\
\hline Questtion 10 & & & & \\
I don't know & $75(25)$ & $48(16)$ & $55(22)$ & $30(12)$ \\
Red, swollen and bleeding gum and tooth mobility & $79(26)$ & $114(38)$ & $83(34)$ & $107(44)$ \\
Red, swollen and bleeding gum & $89(29)$ & $98(32)$ & $88(36)$ & $88(36)$ \\
Red gum, bad breath and tooth loss & $28(9)$ & $19(6)$ & $15(6)$ & $10(4)$ \\
Red gum, yellow tooth and bad breath & $32(11)$ & $24(8)$ & $4(2)$ & $10(4)$ \\
& & & & \\
Question 11 & & & & \\
I don't know & $140(46)$ & $88(29)$ & $124(51)$ & $56(23)$ \\
Red, swollen and bleeding gum and tooth mobility & $58(19)$ & $68(22)$ & $35(14)$ & $75(31)$ \\
Red, swollen and bleeding gum & $32(11)$ & $50(17)$ & $22(9)$ & $32(13)$ \\
Red gum, bad breath and tooth loss & $0(0)$ & $0(0)$ & $0(0)$ & $0(0)$ \\
Red gum, yellow tooth and bad breath & $73(24)$ & $97(32)$ & $64(26)$ & $82(33)$ \\
\hline
\end{tabular}


Table 5 - Chi-square test $\left(\chi^{2}\right)$ applied to compare the groups (GA, GB) about schoolchildren's knowledge after two weeks from program execution. Araraquara, 2005.

\begin{tabular}{|c|c|c|c|}
\hline & QUESTIONS & $\chi^{2}$ & $\mathbf{P}$ \\
\hline 1. & Sugary food has to be consummated: & 0.141 & 0.7074 \\
\hline 2. & Eating sugary food exaggerated may cause: & 0.144 & 0.7045 \\
\hline 3. & Group of food that are related to dental caries: & 20.933 & $0.0000^{*}$ \\
\hline 4. & What has to be observed during the meal to avoid dental caries? & 0.118 & 0.7312 \\
\hline 5. & Teeth have to be brushed: & 14.369 & $0.0002^{*}$ \\
\hline 6. & Does a baby to brush her/his teeth? & 26.984 & $0.0000^{*}$ \\
\hline 7. & What is dental plaque? & 0.511 & 0.4748 \\
\hline 8. & Dental plaque may cause: & 4.898 & $0.0269 *$ \\
\hline 9. & What do we haveto do to avoid dental plaque? & 0.297 & 0.5855 \\
\hline 10. & What is gingivitis? & 0.772 & 0.3795 \\
\hline 11. & What is periodontitis? & 4.689 & $0.0304^{*}$ \\
\hline
\end{tabular}

${ }^{*}$ Statistical significance level of $5 \% \cdot \chi^{2}=$ qui-square; $P=$ probability

Table 6 - McNemar test applied to compare each group (GA, GB) in the moments before and after program execution regarding the knowledge of the school children. Araraquara, 2005.

\begin{tabular}{|c|c|c|c|c|c|}
\hline & QUESTIONS & $\chi^{2}$ & $\mathbf{P}$ & $\chi^{2}$ & $\mathbf{P}$ \\
\hline 1. & Sugary food has to be consummed: & 0,1607 & 0,6885 & 3,5208 & 0,0606 \\
\hline 2. & Eating exaggeratedly sugary food may cause: & 0,3214 & 0,5708 & 0,0000 & 1,0000 \\
\hline 3. & Group of food that are related to dental caries: & 0,1286 & 0,7199 & 70,7789 & $0,0000^{*}$ \\
\hline 4. & $\begin{array}{l}\text { What have to be observed during the meal to avoid dental } \\
\text { caries? }\end{array}$ & 14,2604 & $0,0002^{*}$ & 8,4767 & $0,0036^{*}$ \\
\hline 5. & Teeth have to be brushed: & 0,0161 & 0,8989 & 18,2785 & $0,0000^{*}$ \\
\hline 6. & Does a baby have to brush her/his teeth? & 0,1286 & 0,7199 & 46,2857 & $0,0000^{*}$ \\
\hline 7. & What is dental plaque? & 0,7356 & 0,3911 & 0,7788 & 0,3775 \\
\hline 8. & Dental plaque may cause: & 0,1000 & 0,7518 & 9,0133 & $0,0027^{*}$ \\
\hline 9. & What do we have to do to avoid dental plaque? & 1,4845 & 0,2231 & 1,5484 & 0,2134 \\
\hline & What is gingivitis? & 0,8312 & 0,3619 & 0,0098 & 0,9211 \\
\hline 11. & What is periodontitis? & 1,0385 & 0,3082 & 18,1071 & $0,0000^{*}$ \\
\hline
\end{tabular}

*Statistical significance level of $5 \% \cdot \chi^{2}=$ qui-square; $P=$ probability

\section{Discussion}

The use of folders and lectures at schools have been commonly observed $(1,9,13)$ as a strategy in educative-preventive programs seeking better oral health. It is important to emphasize that the informative material used in this study was prepared by the team themselves, as well as the development of the proposed program and which was edited and published by Araraquara University Center - UNIARA after been tested during 12 months at the Clinic of Collective Health on Deontology from this institution.
Besides the content of the folder, others aspects were carefully planned, as the use of pages with different colors according to each theme (dental caries, periodontal disease, feeding, oral hygiene), and using illustrative draws that offer more interactivity with reader. However, verifying Tables 1 to 6, it may be noted that the isolated use of the folder was not able to arouse interest of schoolchildren, what might have occurred because this kind of material demands individual initiative in searching new information or 
that, according to Oliveira and Chadwick ${ }^{14}$ (2001), it is necessary that each school child be aware that he/ she is an essential component of the development of an intrinsic motivation to learn.

Regarding the lectures, differently of the use of folders, schoolchildren assume a passive position on learning, what means that, they do not need to search information because this was transmitted verbally as soon as the folders were distributed and this allowed them to learn the whole content without even browsing through it.

Tables 5 and 6 confirm this fact when it is noted the statistical difference in the knowledge acquired by schoolchildren from both groups after 15 days in five questions and when evaluation was intragroup it was noticed a better performance of group B in comparison to group A, showing that the participants who received lectures have absorbed more information then the others.

Themes presented in this program were selected because of their importance on oral health maintenance. In relation to feeding the purpose was to know schoolchildren understanding about sugary food consumption and its relation with the development of tooth decay lesions.

For the answers showed (Table 1) it was observed that in spite of most of the school children relate tooth decay to the consumption of sugary food, when they were asked about groups of food that could cause it, they attributed this responsibility to lipid, what may have occurred due to their lack of knowledge regarding to classification and composition of various macronutrients and therefore, they were not able to associate sugary food with carbohydrates.

Still regarding to feeding, , some authors believe that it is necessary a thoughtful choice of type of food to be consummated to prevent tooth decay without taking in consideration the consistence and frequency of ingestion that are fundamental features that may define if food will influence on etiology of dental caries ${ }^{12}$.

In respect to oral hygiene (Table 2), it was verified that many schoolchildren affirmed a necessity to toothbrushing four times a day, what is in accordance with studies from Garcia et al. ${ }^{8}$ (2004), and this conduct correspond to frequent information transmitted by the media in our country.

It is interesting to emphasize that many school children had a misconception flossing (Table 3 ), since they mentioned its use only to remove food scraps impacted among teeth. Such observation was also noted in study from Campos and Garcia ${ }^{5}$ (2003) and Santos et al. ${ }^{16}$ (2003), when evaluating knowledge from schoolteachers of primary schools, showing the influence of popular beliefs, stimulating few use of dental floss.

These were thoughts consolidated throughout time originated in beliefs and were also found by Vigild et al. ${ }^{19}$ (1999) which verified that the main source of information about oral health from 12-years-old schoolchildren were their parents (74\%) followed by dentists and teachers. So, it is understood that educative programs' working out at school have to aim not only the children but also the parents which is a very important strategy and the primary intention of this study when the preparation of informative folders.

Another relevant aspect is the difficult to conceptualize periodontal disease by schoolchildren (Table 4), and this might have occurred due to most of educativepreventive programs of oral health proposition to infantile population emphasizing tooth decays as the main oral disease to be prevented, leading to greater familiarity of this population to dental caries features. Reinforcing this statement, it is interesting quote that Rajab et al. ${ }^{15}$ (2002) evaluated 1556 children from 6 to 16 -years-old and they noted that $79 \%$ of them associated lack of oral hygiene to development of dental caries lesion only.

Although knowledge about oral health isolated are not able to guarantee a lasting change of behavior (11), this is an important fact to stimulate the incorporation of healthy habits in life and plan e evaluate oral health actions ${ }^{2}$. So, it becomes necessary to stress that the development of this program has taken in consideration the needs of the target population and the way it was performed was only the first step to the elaboration and implantation of a continuous program to be kept by this institution in the future.

In this way, it is suggested that strategies to stimulate reading and the application of this material continuously have to be thought with the intent to arouse interest and making learning about oral health a pleasant activity.

\section{Conclusion}

Observing the previous propositions, it may be concluded that the folder used isolated was not able to add information about oral health to evaluated schoolchildren while its association with lectures acted improving knowledge of the studied population. 


\section{Resumo}

O objetivo do estudo foi avaliar dois diferentes métodos educacionais: folheto explicativo e palestras, na implementação de um programa educativo-preventivo sobre saúde bucal em escolas públicas do município de Araraquara (SP). A amostra constituiu-se de escolares das $5^{\circ}$ e $6^{\circ}$ séries de quatro escolas, divididos aleatoriamente em dois grupos: GA $(n=303)$ recebeu somente o folheto explicativo; GB $(n=245)$ recebeu folheto e freqüentou palestra. Utilizou-se questionário com 11 questões objetivas, antes e decorridos 15 dias do programa. Realizou-se a distribuição de frequiências e em seguida, a comparação intergrupos pelo teste de qui-quadrado, e intragrupos pelo teste de $\mathrm{McNemar}(\alpha=0,05)$. A maioria dos escolares entende que o consumo de alimentos açucarados deve ocorrer após as principais refeições e relaciona o consumo de açúcares com cárie, porém não sabe que pertencerem ao grupo dos carboidratos. Uma refeição saudável depende somente do tipo de alimento para $52 \%$ do GA e $44 \%$ do GB, antes, e $48 \%$ e $39 \%$, decorridos 15 dias. Inicialmente, apenas $31 \%$ do GA e $30 \%$ do GB sabiam o momento ideal da escovação. Os métodos de prevenção de placa foram familiares aos escolares. Houve dificuldade para definir as características da doença periodontal. Na avaliação intergrupos, houve diferença estatística para as questões 3, 5, 6, 8 e 11; e intragrupos o GA apresentou alteração significativa no conhecimento apenas para questão 4 enquanto no GB, o mesmo ocorreu para as questões $3,4,5,6,8$ e 11 apontando maior efetividade do método adotado no GB. O folheto utilizado isoladamente não acrescentou informações sobre saúde bucal para os escolares avaliados enquanto, este associado a palestra melhorou o conhecimento do grupo.

\section{UNITERMOS}

Ensino fundamental; educação em saúde bucal; materiais de ensino.

\section{REFERENCES}

1. Abe S, Furukawa S, Shinada K, Kawaguchi Y. Coverage by Japanese newspapers of oral health messages on the prevention of dental caries. J Med Dent Sci. 2005;52(1):17-25

2. Biesbrock AR, Walters PA, Bartizek RD. Initial impact of a national dental education program on the oral health and dental knowledge of children. J Contemp Dent Pract. 2003;4(2):1-10.

3. Burghardt JA, Devaney BL, Gordon AR. The school nutrition dietary assessment study: summary and discussion. Am J Clin Nutr. 1995 Jan;61(1 Suppl):252S-57S.

4. Burt BA. The prevention connection: linking dental health education and prevention. Int Dent J. 1983 Jun;33(2):188-95.

5. Campos JADB, Garcia PPNS. Prevenção de cárie e comportamento de higiene bucal: conhecimento de professores do ensino fundamental. Rev ABOPREV. 2003;6(2):26-35.

6. Chikte U, Brand AA, Gilbert L. The suitability of teachers as oral health educators. J Dent Assoc S Afric. 1990 Oct;45(10):429-32.

7. Farsi JM, Farghaly MM, Farsi N. Oral health knowledge, attitude and behaviour among Saudi school students in Jeddah city. J Dent. 2004 Jan;32(1):47-53.

8. Garcia PPNS, Campos JADB, Nogueira I, Dovigo LN. Conhecimento de saúde bucal em escolares: efeito de um método de auto-instrução. Rev Odontol UNESP. 2004;33(1):41-46.

9. Leal MF, Oliveira CCC. Avaliação de um programa preventivo em escolares de 6 a 14 anos, do ensino fundamental em Aracaju/SE. Rev ABOPREV. 2002;5(2):17-26.

10. Mastrantonio SDS, Garcia PPNS. Programas educativos em saúde bucal - revisão de literatura. J Bras Odontoped Odontol Bebê. 2002;5(25):215-22.

11. Mayer MP, Paiva Buichi Y, Oliveira LB, Gjermo O. Long-term effect of na oral hygiene training program on knowledge and reported behavior. Oral Health Prev Dent. 2003;1(1):37-43.

12. Mobley CC. Nutrition and dental caries. Dent Clin N Am. 2003;47:319-36.
13. Mwangosi IEAT, Mwakatobe KM, Astrom ANK. Sources of oral health information and teaching materials for primary schoolteachers in Rungwe district, Tanzania. Int Dent J. 2002 Dec; 52(6): 469-74.

14. Oliveira JBA, Chadwick C. Aprender e ensinar. 3ed. São Paulo: Global; 2001. 395p.

15. Rajab LD, Petersen PE, Bakaeen G, Hamdan MA. Oral health behaviour of schoolchildren and parents in Jordan. Int Dent J. 2002;12:168 76.

16. Santos PA, Rodrigues JA, Garcia PPNS. Conhecimento sobre prevenção de cárie e doença periodontal e comportamento de higiene bucal de professores de ensino fundamental. Cienc Odontol Bras. 2003 jan./ mar;6(1):67-74.

17. Tai B, Du M, Peng B, Fan M. Experiences from a school-based oral health promotion programme in Wuhan city, PR China. Int J Paediatr Dent. 2001;11:286-91.

18. Tamietti MB, Castilho LS, Paixão HH. Educação em saúde bucal para adolescentes: inadequação de uma metodologia tradicional. Arquivos Odontol. 1998 jan./jun.;34(1):33-45.

19. Vigild M, Petersen PE, Hadi R. Oral health behaviour of 12-year-old children in Kuwait. Int J Paediatr Dent. 1999 Mar;9(1):23-9.

20. Waldman HB. Do parents know how best to feed their children? Maybe not! J Dent Child. 1998 Sept/Oct.;65(5):335-8.

Recebido em 14/08/07 Aprovado em 12/06/08

Correspondence to: Patrícia Aleixo dos Santos Rua Benedito Jesus Santos Miguel, 75 - apto 10 CEP:14810-128 Araraquara - SP Brazil. Email: patyaleixo01@yahoo.com.br 